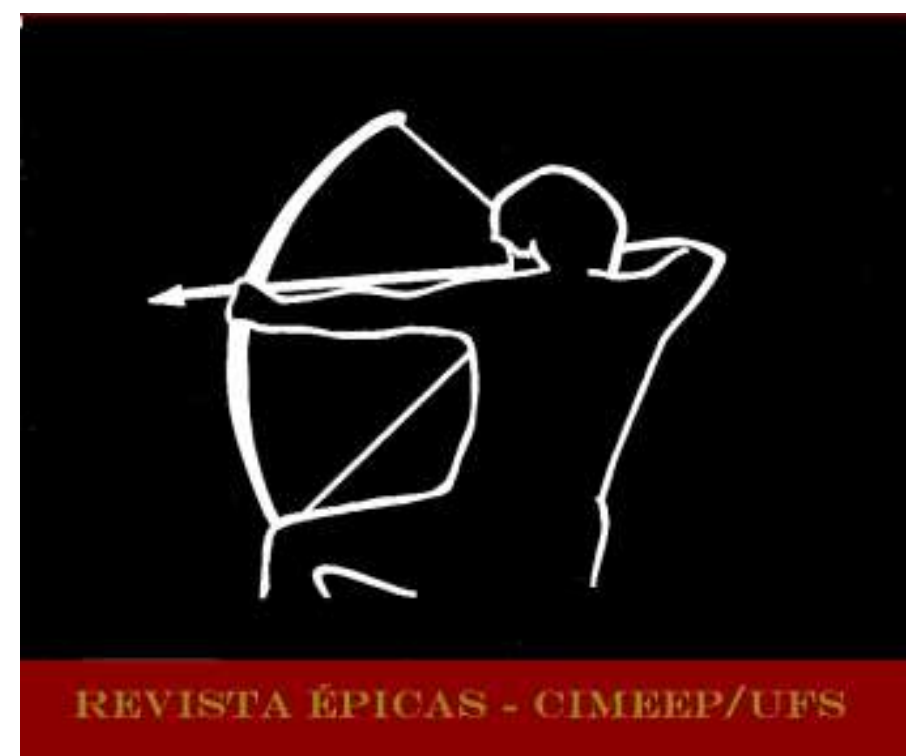

CÔRTES, Daynara L. A.; SANTOS, Jeane de C. N.. Entre a guerrilha e a literatura: dimensões épicas no romance Mayombe de Pepetela. In: Revista Épicas. Ano 4, N. 7, Jun 2020, p. 1-15. ISSN 2527-080-X.

\title{
ENTRE A GUERRILHA E A LITERATURA: \\ DIMENSÕES ÉPICAS NO ROMANCE MAYOMBE, DE PEPETELA
}

\section{ENTRE LA GUERRILLE ET LA LITTÉRATURE: \\ DIMENSIONS ÉPIQUES DANS LE ROMAN MAYOMBE ROMANCE, PAR PEPETELA}

\author{
Daynara Lorena Aragão Côrtes ${ }^{1}$ \\ Jeane de Cassia Nascimento Santos ${ }^{2}$ \\ Universidade Federal de Sergipe
}

RESUMO: O romance Mayombe (1980) nos traz em seu enredo a reconstituição da Guerra de Libertação de Angola por meio da atuação de personagens guerrilheiros em disputa pela libertação política nacional. O plano histórico da guerra, contemporâneo ao período de escrita da obra, envolve uma estrutura narrativa polifônica, cuja multiplicidade de vozes e perspectivas apresenta a diversidade interna que compunha os grupos políticos locais com destaque ao MPLA - Movimento Popular de Libertação de Angola. Neste texto, investigamos como o trabalho estético se funde às orientações políticas empregadas, uma vez que a disposição dos elementos épicos de narração, proposição, invocação, dedicatória e epílogo arquitetam o desenvolvimento heroico de alcance mitológico, e como o heroísmo histórico individual associado ao coletivo assume na tessitura narrativa pepeteliana uma africanidade de cunho combativo. Para isso, fizemos uso, sobretudo, das contribuições teóricas de Mikhail Bakhtin (2002), Anazildo Vasconcelos da Silva (1984), Christina Ramalho (2013, 2016), Maria Aparecida Santilli (1985), Tania Macêdo e Rita Chaves (2007).

Palavras-chave: Mayombe; Pepetela; Literatura épica; Identidade nacional.

RÉSUMÉ: Le roman Mayombe (1980) apporte dans son intrigue la reconstitution de la guerre de libération de l'Angola par l'action de guérilleros en litige pour la libération politique nationale. Le plan historique de la guerre, contemporain de la période d'écriture de l'œuvre, implique une structure narrative polyphonique, dont la multiplicité des voix et des perspectives présente la diversité interne qui a constitué les groupes politiques locaux en mettant l'accent sur le MPLA - Mouvement Populaire pour la Libération

\footnotetext{
${ }^{1}$ Mestre em Estudos Literários (UFS, 2020).

2 Doutora em Estudos Comparados de Literaturas de Língua Portuguesa) pela Universidade de São Paulo (USP, 2007). Professora-Associada do Curso de Letras da Universidade Federal de Sergipe.
} 
de l'Angola. Dans ce texte, nous étudions comment le travail esthétique fusionne avec les orientations politiques utilisées, depuis la disposition d'éléments épiques de narration, proposition, invocation, dévouement et épilogue architectent le développement héroïque de portée mythologique, et comment I'héroïsme historique individuel associé au collectif suppose dans le tissu narratif pépétélien une africanité de nature combative. Pour cela, nous avons principalement utilisé les contributions théoriques de Mikhail Bakhtin (2002), Anazildo Vasconcelos da Silva (1984), Christina Ramalho (2013, 2016), Maria Aparecida Santilli (1985), Tania Macêdo et Rita Chaves (2007).

Mots clés: Mayombe; Pepetela; Littérature épique; Identité nationale.

\section{Considerações iniciais}

O angolano nascido em Benguela, Artur Carlos Maurício Pestana dos Santos, mais conhecido como Pepetela, é um autor reconhecido nacional e internacionalmente. Alguns dos muitos prêmios recebidos fizeram com que a sua popularidade e a expansão da sua produção recebessem um alcance significativo. Destaca-se, entre eles, a conquista, em 1997, do Prêmio Camões, considerado um dos títulos de maior prestígio dentro do cenário cultural literário da língua portuguesa.

No Brasil, a recepção da literatura pepeteliana é abrangente. São muitas as universidades que acolhem o desenvolvimento de trabalhos de graduação e pós-graduação com base na escrita do autor sob diversos vieses. A (re)construção de Angola é, certamente, um dos temas que mais saltam no meio dessa fortuna crítica que tem muito a se desenvolver, ganhando novos rumos interpretativos acerca tanto da produção particular do autor quanto da coletiva da literatura angolana.

Tratar das dimensões épicas do romance Mayombe, de primeira publicação em 1979, requer confrontar guerrilha e literatura, visto que o plano histórico e o plano maravilhoso são literariamente engendrados, no fio narrativo que contempla a Guerra de Independência Angolana (1961-1974). Sendo esses três planos - o histórico, o maravilhoso e o literário categorias fundamentalmente inerentes à criação épica, vale ressaltar que o próprio conjunto da obra de Pepetela traz essa característica de interpenetrar história e mito por meio da criação estético-literária, com destaque para a representação da guerra. Nesse sentido, lembramos a obra A geração da utopia (1992), na qual o cenário de guerra ocupa as páginas do romance nos apresentando cronologicamente os meandros históricos pré e pós independentistas que datam os anos de 1961 a 1991 entre Lisboa e Luanda.

A união entre a literatura e a guerra é tema caro no panorama literário mundial do século XX. Sobretudo, pelo fato de termos testemunhado relatos de duas grandes catástrofes que, direta e indiretamente, feriram a todas e todos globalmente. As duas grandes guerras Primeira Guerra Mundial (1914-1918) e Segunda Guerra Mundial (1939-1945) - colocaram no cenário mundial o nível último da crueldade em face da ideia de humanidade, tal como, por 
comparação, ocorreu com a colonização na África e nas Américas e as consequências deixadas desde o século XV até a contemporaneidade.

Na leitura da passagem para a chamada "era da modernidade" pelos avanços técnicos, Walter Benjamin, em Documentos de cultura, documentos de barbárie (1986), tece considerações importantes a título de introdução das análises desenvolvidas no decorrer deste trabalho. Vejamos a sua interpretação acerca das transformações próprias desse período antagônico de grandes avanços, mas também de grandes retrocessos:

Jamais houve experiências tão desmoralizadas como as estratégicas pela guerra de trincheiras, as econômicas pela inflação, as físicas pela fome, as morais pelos donos do poder. Uma geração que ainda fora à escola de bonde puxado por cavalos, viu-se desabrigada, numa paisagem onde tudo, exceto as nuvens, havia mudado, e em cujo centro, num campo de forças de explosões e correntes destruidoras, estava o minúsculo e frágil corpo humano. Uma miséria totalmente nova se abateu sobre o homem com esse desenvolvimento monstruoso da técnica (BENJAMIN, 1986, p. 195).

O cenário caótico mundial, sob a perspectiva de um olhar centrado na Europa, aponta para esse ser esfacelado diante dos horrores de um período marcado por tragédias resultantes de disputas econômicas no desenvolver de uma conjuntura geopolítica em duelo contínuo pela expansão e dominação de territórios.

Simultaneamente, no abrir de portas do século XX, a África Lusa, ainda sob domínio colonial, padecia de situação semelhante, que advinha de um passado escravocrata duradouro, que deixou fronteiras marcadamente expressas em toda uma população mundial em diáspora. O colonialismo revelava a sua mais cruel face em resposta às organizações independentistas que surgiam na luta pela emancipação política. Fora, como escreveram Tania Macêdo e Rita Chaves em Literaturas de língua portuguesa: marcos e marcas - Angola (1985), um período de resistência também literária que começava a despontar (MACÊDO; CHAVES, 2007, 1985, p. 26).

Em Angola, nesse contexto, as organizações de escritores moviam-se à medida que o projeto de uma Angola independente tomava força. A construção da identidade nacional mediava as disputas narrativas. Na década de 1940, sistematicamente, a circulação de textos acontecia por meio, principalmente, de revistas, entre as quais se inclui Mensagem (1949) e Cultura (1957). O objetivo central dos novos canais de comunicação era a "busca da redefinição e valorização dos dados básicos de caracterização nacional. Os escritores propunham-se à alfabetização e melhoria das condições culturais do operário, a diversificadas atividades no setor da cultura nacional" (SANTILLI, 1985, p. 15).

Essa geração, no entanto, não se afastou da oratura. Ao contrário, buscou, por meio da oralidade, construir formas de superação aos novos impasses. Assim, surgiu o movimento "Vamos descobrir Angola" que marcou o ano de 1948. Foi esse grupo que viria a influenciar a 
geração de vinte anos depois. É o caso da Geração de 1960, a qual Pepetela fez parte. Desse modo, trataremos do enredo do romance Mayombe a partir da estrutura épica narrativa aliada ao elemento espaço, cuja simbologia mítica da floresta - compondo o plano maravilhoso acolhe a guerrilha a partir de um olhar que vem de dentro. Ou seja, de alguém que assistiu e viveu o conflito na busca pela emancipação somente outorgada em 1975.

\section{A Guerra de Independência Angolana (1961-1974): uma matéria épica?}

Segundo Christina Ramalho, em Poemas épicos: estratégias de leitura (2013) um dos aspectos que definem a natureza épica de uma obra é a presença temática de uma matéria épica, ou seja, de um tema em que história e mito estão imbricados, daí a importância de se reconhecerem os planos histórico e maravilhoso em obras épicas e, principalmente, compreender como o autor ou a autora que criou o texto épico - e este é o "plano literário" da obra - articulou esses dois planos. Nesse sentido, cabe ressaltar que mesmo matéria épicas que tenham origem na oralidade (definindo uma oratura) não prescindem de mecanismos de seleção e exclusão de fatos e de trabalho com recursos da expressão oral para "contar" ou "relatar" essas matérias.

Em "Método de abordagem ao poema épico" (2016), Ramalho destaca que o plano histórico de uma epopeia é composto através de recursos de referenciação de que o plano literário dispõe para compor uma revisitação de determinado evento histórico, criando (e recriando) seus cenários à luz das motivações de quem o escreveu. São versões/recriações de eventos que podem ser explicitamente referenciados, quando a obra informa diretamente fontes históricas nas quais se baseou, ou que podem estar diluídos na escrita literária, sem a preocupação de sublinhar essas fontes. Por isso, essa presença do plano histórico, elaborado pelo plano literário, não apresenta "formas abstratas", mas interpretações de fatos concretos por meio de formas poéticas autônomas, que, entretanto, não perdem o vínculo com a história como fato. O plano literário, portanto, envolve o investimento na densidade semântica das simbologias e metáforas que o próprio enredo agrega.

Algumas características inscrevem a elaboração dos planos histórico e maravilhoso no épico tomados a partir da voz que narra, seja o eu-lírico/narrador - quando a obra se trata de uma epopeia, caracterizada pela dupla instância de enunciação - ou o narrador épico — quando a obra é um romance épico. Entre essas características estão a apresentação do tema ou matéria épica. Essa apresentação é teoricamente nomeada como "proposição épica".

A observação da presença da proposição épica em uma obra envolve três parâmetros: a forma de inserção da apresentação da matéria épica no corpo da obra; o conteúdo em si; e o 
possível centramento da proposição em determinado(s) aspecto(s) da matéria épica. Desdobram-se, por conseguinte, nas epopeias: a proposição não nomeada integrada ao primeiro canto; a nomeada em destaque e em forma de prosa; a nomeada em destaque e em forma de poema; as proposições múltiplas, dispersas ou multifragmentadas; e a proposição ausente. O conteúdo de uma proposição pode ser referencial, simbólico ou metalinguístico. Quanto ao centramento da proposição, pode-se reconhecer o enfoque no feito heroico; na figura do herói; no plano histórico; no plano maravilhoso; e mesmo no plano literário; além das proposições em que a matéria épica é trabalhada em sua dimensão mais ampla (RAMALHO, 2016, p. 21).

Sendo essas categorias importantes na composição do gênero em debate, nota-se a importância de abandonar a dualidade que defende a existência do épico e do não-épico por meio do purismo de um padrão clássico legítimo. Contrariamente, faz-se necessário identificar "os elementos básicos inerentes à natureza épica do discurso e, a partir daí, [procurar] estabelecer as mudanças geradas pela influência de novas concepções literárias" (RAMALHO, 2016, p. 19).

No que se refere ao romance de Pepetela escolhido para a leitura aqui proposta, Mayombe (1979), é fácil nele reconhecer a presença dos aspectos épicos elencados por Ramalho. Assim, podemos dar à obra um tratamento crítico que a reconheça como uma narrativa épica e, a partir disso, verificar a plausibilidade de reconhecer e mesmo dimensionar se e como as categorias invocação, divisão em cantos, plano histórico, plano maravilhoso, plano literário e heroísmo épico nela se fazem presentes. Mas faz-se necessário fundamentar melhor essa associação entre Mayombe (1979) e o épico.

Com as modificações impressas pelo tempo, o gênero épico seguiu se reinventando, trazendo à produção literária manifestações discursivas e nuance estruturais diversificadas. 0 hibridismo, como marca da produção literária contemporânea, é o tom de tais textos que seguem ampliando o repertório. Em tal caso, a partir das modificações empreendidas por uma "semiotização épica do discurso", estudo desenvolvido por Anazildo Vasconcelos da Silva nos anos de 1980, percebemos os ganhos de perspectivas crítico-evolutivas da epopeia. Logo, isso fez diferenciar a épica da narrativa de fiç̧ão cujo trajeto de ambas é contrastante no arcabouço da literatura ocidental (SILVA, 1984).

Uma epopeia, pela perspectiva de Anazildo Silva (1984), define-se, em primeiro plano, como obra que desenvolve uma matéria resultante da fusão de duas dimensões, real e mítica, que é, por isso, capaz de atribuir significados ao(s) evento(s) histórico(s). Além disso, uma epopeia possui a dupla instância de enunciação, por ser um poema e, ao mesmo tempo, por contar (narrar) uma história. Segundo o autor, o retorno às definições clássicas aristotélicas, às 
narrativas homéricas e lusitanas (no que se refere aos estudos das literaturas em língua portuguesa), trabalhadas de modo dialógico e reconhecendo o movimento de trânsito entre o passado e o presente e as marcas trazidas pelas transformações sociais e estéticas do mundo, permitem destituir da produção épica a rigidez que lhe foi conferida por uma tradição teórica que ignorou ou deu pouca relevância às transformações do gênero e às formas híbridas. Silva salienta que chamar um romance épico de epopeia se trata de um equívoco teórico, visto que o romance não possui a instância de enunciação lírica. No entanto, a nomeação "romance épico" é adequada sempre que uma obra do gênero desenvolve uma matéria épica.

Por esse prisma, como analisar a introdução de um gênero originalmente ocidental na formação da literatura africana de língua portuguesa, especificamente, da literatura angolana? Contextualizando a produção pepeteliana, Inocência Mata em "Pepetela: um escritor (ainda) em busca da utopia" reflete:

Num tempo distópico, atravessado pelo desencanto e pela perda da inocência, o tempo pós-colonial, Memória e História são agora matrizes do novo discurso da identidade cuja topologia passa também pela revitalização de um passado e o questionamento de um passado mítico, construído sobre uma mística do heroísmo e do épico, em que radica o discurso nacionalista (MATA, 1999, p. 253)

A fase embrionária do discurso literário pepeteliano, em um período de intensas repressões, já apresenta os encaminhamentos do que viria a ser o retorno à história de forma mítica. As condições históricas dentro de um fervilhar de disputas, cuja ação anticolonial enredou as ações coletivas sistematizadas, a exemplo da atuação da Geração de 1960 como um paradigma, ofereceram um arranjo simbólico-imagético fecundo para a literatura de guerra como um projeto nacional. Buscar na tradição ocidental esse impulso faz todo sentido, tendo em vista o mais conhecido conflito bélico narrado na llíada e na Odisseia.

Passar pelo crivo da nacionalização dos bens materiais e imateriais com a forte influência europeia por meio do processo de aculturação de um passado sob dominação colonial foi o grande desafio. A influência ocidental exercida, nesse caso, não retira o caráter legítimo da unicidade e do engenho empregado à construção da angolanidade no campo da arte literária. Contrariamente, ainda é possível visualizar aproximações de ordem discursiva, embora exista um lapso de tempo significativo entre os reconhecidos escritores do épico clássico e a geração que compunha a luta política independentista. Atenta-se à escrita em versos retomada nas palavras de Ana Mafalda Leite: "Formalmente, os poemas épicos africanos aglomeram vários gêneros, microgéneros ditirâmbicos, canções populares, amplificando-se e orientando a matéria histórica para o mito" (LEITE, 1987, p. 38).

Diante disso, o estudo de Anazildo Vasconcelos da Silva supracitado recebe uma outra dimensão. A partir de pesquisas que focam nas marcas épicas na produção literária angolana, 
são lançados no além-mar, ao encontro da África, aspectos que comprovam os laços existentes entre a tradição épica ocidental e a escrita de Pepetela, em particular, pela formatação estrutural e discursiva do romance Mayombe.

Em Mayombe, os elementos estruturantes da narrativa - enredo, narrador, personagem, tempo e espaço - são abordados a partir do enfoque nas culturas angolanas ligadas às etnias locais e à tradição oral. Carlos Ervedosa, por exemplo, na introdução de Roteiro da literatura angola, explana essa marca, pois, a literatura dos povos de Angola "possui, tal como a música, a dança, ou a escultura, uma função social milenarmente estabelecida, mas acusa já, em variados aspectos, uma evolução, quer de forma, quer de tema, acompanhando as formas sócio-económicas" (ERVEDOSA, 1979, p. 7). No entanto, uma travessia que também agrega as influências externas é reconhecível a partir de leituras mais abrangentes.

Essa travessia acontece, na Literatura Brasileira, por exemplo, por meio de um projeto reconhecido pelo público leitor após a realização da Semana de Arte Moderna (1922), sob égide do projeto de "antropofagia cultural", teorizado por Oswald de Andrade. No cerne da literatura angolana do século XX, distante dos grandes feitos ocidentais, o espaço mítico é africano - a floresta do Mayombe - e o personagem heroico é negro e coletivo - guerrilheiros que compunham a ação anticolonial. No entanto, estruturalmente, essas representações guardam correspondência com a tradição épica universal que, seja na forma oral (ainda fortemente presente no contexto africano como um todo) seja na forma de uma produção épica literária, reflete a própria experiência humano-existencial. Em Mayombe, os planos histórico e maravilhoso estão diluídos, mas não deixam de trazer à tona simbologias retóricas, líricas e ficcionais, tal como Ramalho (2016) tratou no plano de orientação para identificação das dimensões épicas no texto literário.

Passaremos, a seguir, às considerações sobre especificidades de Mayombe que a aproximam do épico.

\section{Entre a emaranhada teia do Mayombe: o cenário épico na narrativa pepeteliana}

Direcionando nosso olhar para o espaço mítico da floresta de Mayombe, lembramos que a referência geográfica da floresta Mayombe de densa vegetação úmida se expande por quatro países: República Democrática do Congo, República do Congo, Gabão e Angola. Todos eles em hemisférios diferentes, uns ao sul e outros ao norte, cuja região montanhosa e fronteiriça acolhe uma diversidade de espécies da fauna e da flora. Esse cenário recheado de mistérios compôs a obra de Pepetela que evidenciou a menção ao espaço como destaque por meio do título. 
Destarte, a luta de libertação política iniciada em 1961 ocorreu em muitos espaços, transformando-os em campos de ação. O movimento de guerrilha angolano, iniciado no interior, expandindo-se para a capital, obteve o seu ponto de insurgência mais alto nos dez primeiros anos, cuja ação declarada contra o império português tomou as ondas dos rádios, sendo maior parte deles comandados pela direção do MPLA - Movimento Popular de Angola, e da população por via direta em luta armada e indireta na contribuição com mantimentos e proteção das ações. Homens e mulheres compunham um exército que se subdividia em vários grupos, os quais são citados na obra em destaque o MPLA e a UPA - União das Populações de Angola, depois transformado no partido FNLA - Frente Nacional de Libertação de Angola. O foco, no entanto, se estende à perspectiva somente dos guerrilheiros, todos homens, do primeiro movimento citado. A ação da única mulher que enreda a trama é da personagem Ondina que compunha o MPLA, atuando como educadora da base de formação.

Os espaços que compunham estruturalmente a obra e a ação das personagens concentram-se, basicamente, entre Mayombe, a floresta que abriga o grupo de guerrilheiros comandados pelo comandante Sem Medo, e a Dolisie, referência direta à cidade pertencente à República do Congo, local estabelecido como um centro administrativo de questões relacionadas à organização interna do MPLA. Na composição híbrida do grupo que mesclam-se entre "Kikongos" e "Kimbundos", os personagens que compunham a ação, colocando-se como narradores em primeira pessoa, além do comandante, são Teoria, Milagre, Mundo Novo, Muatiânvua, Chefe de Depósito, André, Chefe de Operações, Lutamos e o Comissário Político. As alcunhas seguem uma tradição das organizações de esquerda no mundo, cuja nomeação acontece por via da avaliação coletiva, protegendo a identidade de registro.

Importa-nos compreender os recursos épicos, por meio do discurso empreendido por Pepetela, ao tratar da representação do espaço da floresta por meio da mitificação alcançada pelo Mayombe e pelos personagens guerrilheiros. O narrador em terceira pessoa ora passa para primeira, na transição íntima das personagens, ora distancia-se pela apresentação do espaço, indica o local de amparo da base guerrilheira. Observemos:

O Mayombe tinha aceitado os golpes dos machados, que nele abriram uma clareira. Clareira invisível do alto, dos aviões que esquadrinhavam a mata, tentando localizar nela a presença dos guerrilheiros. As casas tinham sido levantadas nessa clareira e as árvores, alegremente, formaram uma abóbada de ramos e folhas para as encobrir. Os paus serviram para as paredes. O capim do teto foi transportado de longe, de perto do Lombe. Um montículo foi lateralmente escavado e tornou-se forno para o pão. Os paus mortos das paredes criaram raízes e agarraram-se à terra e as cabanas tornaram-se fortalezas. E os homens, vestidos de verde, tornaram-se verde como as folhas e castanhos como troncos colossais. [...] Assim foi parida pelo Mayombe a base guerrilheira (PEPETELA, 2013, p. 67). 
A fusão das características da floresta e das personagens agrega-se ao plano de ação costurado em toda a narrativa. A constituição de um "novo homem" é relacionada à formação de uma nova nação, que é realizada pela guerra e pela humanização suscitada a partir da íngreme experiência na vegetação densa. A situação limite entre a vida e a morte revela os mais íntimos desejos e sensações na revelação de si mesmo. Tal circunstância Pepetela viveu.

O heroísmo individual, por via das ações justificadas em primeira pessoa, e o heroísmo coletivo, devido à atuação em grupo motivada pela aspiração comum de lograr da independência política, colocam à mostra os elementos básicos discursivos ligados à tradição épica. Vejamos o que diz Ramalho sobre o heroísmo épico:

Quanto à ação heroica [...] é interessante observar se a mesma se relaciona diretamente a feitos bélicos e/ou políticos; feitos aventureiros; feitos redentores; feitos artísticos; feitos cotidianos; feitos alegóricos e feitos híbridos. Essa classificação considera a ação heroica em termos gerais (RAMALHO, 2016, p. 30).

Partindo dessa classificação, observamos que, no romance, os guerrilheiros atravessam e executam feitos bélicos e aventureiros, os quais dialogam com um "fazer artístico" dado pela criatividade na elaboração de alternativas para manterem-se vivos em meio às circunstâncias mais perversas; como a ausência de amparo estrutural que inclui a moradia e a alimentação, assim como, pelo drible na carência suscitada pela solidão. Na continuidade, temos a passagem que denota a caracterização heroica dos guerrilheiros encorajados pela mística da floresta, desafiando Zeus:

A mata criou cordas nos pés dos homens, criou cobras à frente dos homens, a mata gerou montanhas intransponíveis, feras, aguaceiros, rios caudalosos, lama, escuridão, Medo. A mata abriu valas camufladas de folhas sob os pés dos homens, barulhos imensos no silêncio da noite, derrubou árvores sobre os homens. E os homens avançaram. E os homens tornaram-se verdes, e dos seus braços folhas brotaram, e flores, e a mata curvou-se em abóbada, e a mata estendeu-lhes a sombra protetora, e os frutos. Zeus ajoelhado diante de Prometeu. E Prometeu dava impunemente o fogo aos homens, e a inteligência. E os homens compreendiam que Zeus, afinal, não era invencível, que Zeus vergava à coragem, graças a Prometeu que Ihes dá a inteligência e a força de se afirmarem homens em oposição aos deuses. Tal é o atributo do herói, o de levar os homens a desafiarem os deuses. Assim é Ogun, o Prometeu africano. (PEPETELA, 2013, p. 68)

A solidariedade tecida em meio à persistência na guerrilha revela a leitura acerca dos laços construídos mesmo diante das diferenças culturais, nomeadas de "tribalismos" quando não reconhecidas de modo agregador, mas também dos laços afetivos amorosos que incluem os sentimentos de amor e ódio em um jogo de oposição linguística. Sem Medo, em diálogo com o Comissário Político, único de nome revelado João, define: "O amor é um duelo. Mas o amor realizado é também uma combinação. [...] O amor é uma dialética cerrada de aproximaçãorepúdio, de ternura e imposição. [...] Não há nada pior no homem que a falta de imaginação. É 
o mesmo no casal, é o mesmo na política" (PEPETELA, 2013, p. 91). Assim, o hibridismo não impede o reconhecimento de um heroísmo coletivo.

Quanto ao plano literário, o traço predominantemente narrativo em prosa não elimina da escrita um traço poético associativo. O hibridismo, nesse caso, se estabelece tanto pela caracterização das personagens, quanto pelo uso da linguagem que mescla motivações heroicas à tradição oral característica da formação literária nacional. São eles heróis motivados por grandes paixões, cuja coragem ultrapassa a fronteira estabelecida pela dominação.

Mesmo diante disso, conforme indica Tania Macêdo e Rita Chaves, há uma forte aproximação dessa produção com o texto jornalístico devido ao momento que Angola atravessava. As pesquisadoras apontam que era preciso reescrever as histórias dos povos, sob a perspectiva do homem africano, não mais como tivera sido nos textos coloniais. Portanto, abandona-se o estereótipo e se insere um cenário heterogêneo. As autoras defendem: "A literatura angolana que reivindica a sua especificidade nacional ao mesmo tempo em que aponta para a necessidade de autonomia da colônia, não se choca, antes acompanha, o texto jornalístico e, de certa maneira, "nasce" com ele" (MACEDO; CHAVES, 2007, p. 36).

Uma das razões que comprovam que a prosa poética traz em sua composição traços característicos do campo discursivo jornalístico é, justamente, o fato de ter sido Mayombe um romance que nasceu de um comunicado de guerra, função atribuída ao escritor Pepetela enquanto guerrilheiro.

$\mathrm{Na}$ continuidade, os conflitos contemporâneos à escrita não se pulverizam ao grande tema, a guerra de independência, mas desaguam nas ambiguidades existentes no entorno dos guerrilheiros: entre heróis e vilões. Distantes das construções imagéticas dos guerrilheiros, de modo positivo ou negativo frente à tarefa histórica, atentemos ao fato de serem eles homens capazes de vergarem o deus-Mayombe aos pés, tornando-se protagonistas lendários, tal qual a leitura de Comissário Político a respeito da atuação do Comandante Sem Medo: "para se manter ele próprio, teria de ficar ali, no Mayombe. Terá nascido demasiado cedo ou demasiado tarde? Em todo o caso, fora do seu tempo, como qualquer herói de tragédia" (PEPETELA, 2013, p. 247).

A atuação épica dos personagens demanda um cenário alusivo ao discurso. Assim, Pepetela o faz. Cada parte da floresta é destacada como pequenas partículas capazes de formar um universo natural místico. As ambientações do espaço são constituídas a partir de enigmas desvendados pelos guerrilheiros que desafiam as coroadas de árvores, descobrindo-se na jornada. A terra recebe a cor verde, mantendo-se por muito tempo escura, visto a impenetrabilidade solar, causando na sensação térmica um estado de umidade perene.

É desse modo que o narrador ambientaliza o espaço épico do deus-Mayombe. Segue sucinto mapeamento: "Só o fumo podia libertar-se do Mayombe subir, por entre as folhas e as 
lianas, dispersando-se rapidamente no alto, como água precipitada por cascata estreita que se espalha num lago" (PEPETELA, 2013, p. 13); “O Mayombe não deixava penetrar a aurora, que, fora, despontava já. As aves noturnas cediam o lugar no concerto aos macacos e esquilos. E as águas do Lombe diminuíam de tom, à espera do seu manto dourado" (2013, p. 17); "Às seis horas escureceu totalmente e eles ainda não tinham descido a montanha. $O$ resto foi feito quase de rastros, na escuridão da montanha traiçoeira, a chuva fustigando o rosto" (2013, p. 46); “A mata era húmida, pingando ainda das folhas. O chão era um pântano escorregadio" (2013, p. 48); "A água estava fresca, quase fria. No Mayombe é sempre cristalina, pois são rios de montanha que correm sobre as pedras" (2013, p. 147); "Angola apresentava-se atrás deles com a forma de montanhas cobertas de mata, o cume afogado nas nuvens" (2013, p. 151); “Como estará o Mayombe? Verde, como sempre” (2013, p. 184); “O dia já nascia e a fronteira estava diante deles. A fronteira manifestava-se por uma linha de montanhas coroadas de árvores" (2013, p. 204); "Só às seis horas os primeiros conseguiriam infiltrar-se pelas copas das árvores, recriando o verde do Mayombe" (2013, p. 211).

Com uma linguagem repleta de subjetividade, as imagens espaciais são construídas por meio da mitificação do cenário e das personagens em trânsito. Além da unidade de ação que permeia o primeiro e o último capítulo, o romance Mayombe é também uma narrativa de reflexão sobre a guerra. Lapsos de calmaria também formam o enredo. São nessas passagens que a intimidade das personagens se revelam, colocando à mostra o modo como interpretavam os encaminhamentos do feito bélico. Isso acontece, maiormente, na atuação do personagem Sem Medo, configurando o que poderíamos chamar de um alter ego do próprio autor dado o sentimento de desencanto quanto ao cenário político pós independência, e pelo fio de esperança deixado na menção à necessidade de adesão à luta.

Diante disso, as novas perspectivas de futuro já apontam para uma fase progressista da história angolana, a qual Sem Medo anuncia em seu leito de morte, ferido em combate: "Olha! A classe operária adere à luta... Já vencemos..." (PEPETELA, 2013, p. 242). Concomitante à afirmação, Maria Santilli situa: "É a ideologia da resistência que já insinua. [...] São já os tempos de recrudescimento da repressão, em consequência dos focos de luta armada pela libertação da África" (SANTILLI, 1985, p. 17-22). E, em especial, sobre a produção pepeteliana, afirma:

Em Mayombe, Pepetela desenvolve técnicas de fiç̧ão que acentuam a literariedade de seu novo texto, revelam a maturidade artística do Escritor, mas que não deixam de resultar num painel, também didático, das tensões internas nos quadros da luta de libertação, quando da guerrilha nas matas do Mayombe. As várias vozes que se alternam na narrativa, questionando-se umas às outras, convertem o texto num corajoso debate, cujo princípio está na perspectiva de autocrítica com que a realidade angolana é, então, apreendida (SANTILLI, 1985, p. 22-23). 
A experiência da guerra é apreendida simbolicamente pela entrega da vida ao território. De semelhante forma à trajetória dos personagens Comandante e Lutamos, que morreram em meio à floresta do Mayombe, sendo realizado o desejo de sepultamento do primeiro no campo de batalha, o escritor Mia Couto constrói a narrativa da personagem protagonista de "As flores de novidade", que integra a obra Estórias abensonhadas (1994). A dissolução do império português, em decorrência da guerra em sua mais alta resistência africana, é feita por meio dos filhos rendidos aos sacrifícios últimos acarretados pela desintegração da nação: “A vida de Sem Medo esvaía-se para o solo do Mayombe, misturando-se às folhas em decomposição. [...] As flores de mafumeira caíam sobre a campa, docemente, misturadas às folhas verdes das árvores. Dentro de dias, o lugar seria irreconhecível. O Mayombe recuperaria o que os homens ousaram tirar-Ihe" (PEPETELA, 2013, p. 244).

\section{Considerações finais}

À vista das análises feitas acerca das dimensões épicas no romance Mayombe, notamos como o caráter híbrido da tradição mescla características muito particulares da formação da literatura angolana. A introdução da Guerra de Independência (1961-1974) por meio dos feitos heroicos dos protagonistas enreda uma trama de aventuras mitológicas, cujo diálogo entre a tradição oral das etnias africanas e a tradição ocidental grega é realizado como uma fusão entre culturas em um contexto de intensas trocas.

Sabemos, no entanto, que essas trocas culturais não devem ser lidas pela ótica da romantização. É como Toni Morrison, em The origin of others [A origem dos outros], refletiu acerca das táticas de domínio: “Cultura, características físicas e religião eram e são, entre todos, precursores de estratégias para a ascendência e o poder" (MORRISON, 2019, p. 47).

As imposições, as assimilações e as reivindicações por meio de signos adaptados à luz de uma visão africana no centro do desenvolvimento narrativo são partes de um processo de reconstrução da angolanidade, uma vez submetidas às diversas formas de aculturação executadas pelo colonialismo. Nota-se pelo questionamento de Muatiânvua em discurso direto, um dos guerrilheiros em combate: "De que tribo?, pergunto eu. De que tribo, se eu sou de todas as tribos, não só de Angola, como de África? [...] A que tribo angolana pertence a língua portuguesa?" (PEPETELA, 2013, p. 121).

Diante disso, a construção de uma sociedade nova, nos parâmetros teóricos que orientam a práxis do grupo, é transformadora. Pretende-se, com a conquista da libertação, edificar novas estruturas sociais que culminariam em novas formas de socialização. Se a Geração de 1960 compartilhava dessas ideias, a partir de um projeto de intensa dedicação no erguer de 
um plano nacional, no qual Pepetela fora participante ativo, as futuras gerações acabaram por refletir os já trilhados caminhos. Essa volta a uma tradição literária traduz bem aquilo que significou uma "vitalidade cultural de Angola", conforme escreveu Carlos Ervedosa em Roteiro da literatura angolana (1979).

Em relação às marcas do épico, como a dimensão mitológica do "deus-Mayombe" é o espaço que, ao passo que ampara a guerrilha, também, recebe uma conotação maior a partir dessa personificação/divinização, a estrutura do romance acompanha as formas épicas marcadas pelo hibridismo do próprio gênero, conforme defendem Anazildo da Silva e Christina Ramalho (2015) ao tratar dos aspectos estruturantes da epopeia.

A narração heroica envolve guerrilheiros na batalha pela conquista da independência nacional. É certo que sujeitos fragmentados, cada um com a sua trajetória particular, se unem a um projeto coletivo de nacionalização das riquezas e reestruturação do país. O enredo é iniciado por uma dedicatória que, logo, enuncia: "Aos guerrilheiros do Mayombe,/ que ousaram desafiar os deuses/ abrindo um caminho na floresta obscura,/ Vou contar a história de Ogun,/ o Prometeu africano" (PEPETELA, 2013, p. 9). A proposição, por sua vez, é feita a partir do cenário que situa os personagens que compunham a operação de guerra no entre as folhas e as lianas, cuja pulverização do foco narrativo intitulado "Eu, o narrador [...]" plurivocaliza o relato (BAKHTIN, 2002). O fragmento - “E os guerrilheiros perceberam então que o deus-Mayombe Ihes indicava assim que ali estava o seu tributo à coragem dos que o desafiavam" (PEPETELA, 2013 , p. 68) - traduz a invocação de dois importantes símbolos: Zeus, divindade maior do Olimpo, e o Prometeu Africano, simbiose dos mitos que enredaram as narrativas literárias ocidentais, agora, a partir da perspectiva anticolonial africana. Já no epílogo narra-se em primeira pessoa a partir do Comissário Político, João, em lamento pela morte de Sem Medo, líder do grupo. É a "metamorfose" a tônica na construção de heróis fragmentados e em crise, tal qual o romance contemporâneo evidencia, como segue: "Em todo o caso, fora do seu tempo, como qualquer herói de tragédia. [...] contemplo o passado e o futuro. E vejo o quão irrisória é a existência do indivíduo. É, no entanto, ela que marca o avanço no tempo" (PEPETELA, 2013, p. 247).

A partir das categorias (narração, dedicatória, proposição, invocação e epílogo) na ordenação de um texto em prosa, a construção do estilo épico mantém o entrelace entre o plano literário, histórico e o plano maravilhoso. Embora não seja dividido em cantos, mas, sim, em cinco capítulos - "A missão", "A base", "Ondina", "A surucucu" e "A amoreira" - é mantida a função episódico-narrativa, espacial, temática e simbólica que pode ser encontrada em muitas epopeias (SILVA; RAMALHO, 2015, p. 23). 
Em síntese, Pepetela no alvorecer do movimento de guerrilha, no qual fora produzido o romance Mayombe, é traduzido até a atualidade como um autor que tem muito a dizer sobre os encaminhamentos políticos e, sobretudo, estéticos das escritas literárias angolanas. Continua sendo ele um porta-voz daqueles que viveram os horrores da guerra, se encantaram politicamente e desencantaram com o contexto de pós independência sem, no entanto, perder a esperança. Desse modo, o campo de ação pepeteliano, agora excepcionalmente a literatura, segue ecoando nacional e internacionalmente por entre os "barulhos imensos no silêncio da noite" (PEPETELA, 2013, p. 68).

\section{Referências}

BAKHTIN, Mikhail. Estética da criação verbal. Tradução de Maria Ermantina Galvão G. Pereira. São Paulo: Martins Fontes, 2002.

BENJAMIN, Walter. Documentos da cultura, documentos da barbárie. São Paulo: Cultix, 1986.

COUTO. Mia. Estórias abensonhadas. São Paulo: Companhia das Letras, 2012.

ERVEDOSA, Carlos. Roteiro da literatura angolana. Lisboa: Edições 70, 1979.

LEITE, Ana Mafalda. A discursividade épica em Mayombe de Pepetela. In: Literaturas africanas de língua portuguesa: compilação das comunicações apresentadas durante o Colóquio sobre Literatura dos Países Africanos de Língua Portuguesa. Org. Manuel Ferreira. Lisboa: Fundação Calouste Gulbenkian, 1987, p. 35-43.

MATA, Inocência. Pepetela: um escritor (ainda) em busca da utopia. SCRIPTA, Belo Horizont, v. 3, n. 5, p. 243-259, 2o sem. 1999.

MACEDO, Tânia. CHAVES, Rita. Literaturas de língua portuguesa: marcos e marcas - Angola. São Paulo: Arte \& Ciência, 2007.

MORRISON, Toni. A origem dos outros. Tradução de Fernanda Abreu. São Paulo: Companhia das letras, 2019.

PEPETELA. A geração da utopia. São Paulo: LeYa, 2013.

PEPETELA. Mayombe. Rio de Janeiro: LeYa, 2013.

RAMALHO, Christina. Método de abordagem ao poema épico. In: Teoria e prática de leitura do texto literário. Organização de Carlos Magno Gomes e Jeane de Cássia Nascimento Santos. São Cristóvão: Editora UFS, 2016.

RAMALHO, Christina. Poemas épicos: estratégias de leitura. Rio de Janeiro: UAPÊ, 2013.

SANTILLI, Maria Aparecida. Estórias africanas: história e antologia. São Paulo: Ática, 1985.

SILVA, Anazildo Vasconcelos da. Semiotização literária do discurso. Rio de Janeiro: Elo, 1984. 
SILVA, Anazildo; RAMALHO, Christina. História da epopeia brasileira. Aracaju: ArtNer Comunicação, 2015. 